\title{
Transforming growth factor- $\beta$ induces collagen synthesis without inducing IL-8 production in mesothelial cells
}

\author{
Y.C.G. Lee*,\#, K.B. Lane*, O. Zoia*, P.J. Thompson`, R.W. Light*,\#, T.S. Blackwell
}

Transforming growth factor- $\beta$ induces collagen synthesis without inducing IL-8 production in mesothelial cells. Y.C.G. Lee, K.B. Lane, O. Zoia, P.J. Thompson, R.W. Light, T.S. Blackwell. (C)ERS Journals Ltd 2003.

ABSTRACT: Conventional pleurodesing agents often provoke acute pleural inflammation followed by fibrosis. The inflammation frequently causes pain and fever. Transforming growth factor (TGF)- $\beta$ is a pro-fibrotic but anti-inflammatory cytokine. Intrapleural TGF- $\beta_{2}$ administration produces effective pleurodesis in animals, but its effects on mesothelial cells are unknown. The authors hypothesised that, unlike conventional pleurodesing agents, TGF- $\beta_{2}$ can induce collagen synthesis without stimulating pleural inflammation.

In the in vitro studies, TGF- $\beta_{2}$, talc and doxycycline were administered to rabbit mesothelial cells for $24 \mathrm{~h}$. These agents were also injected intrapleurally in rabbits and the induced pleural fluids collected at $24 \mathrm{~h}$. TGF- $\boldsymbol{\beta}_{2}$ was as potent as talc and doxycycline in upregulating mesothelial cell collagen expression.

Talc and doxycycline both induced significant increases in interleukin (IL)-8 production from mesothelial cells in vitro and in rabbit pleural fluids in vivo. TGF- $\beta_{2}$, however, did not stimulate mesothelial cell IL-8 release in vitro and induced a dosedependent suppression of pleural fluid IL-8. Pleural fluid IL-8 levels correlated significantly with leukocyte and lactate dehydrogenase concentrations in the fluids.

In summary, transforming growth factor- $\beta$ was a potent inducer of mesothelial cell collagen synthesis. Unlike talc and tetracycline, which provoked pleural inflammation, transforming growth factor- $\beta_{2}$ suppressed pleural inflammation in vivo. Transforming growth factor- $\beta_{2}$ can produce effective pleural fibrosis without necessitating acute pleural inflammation.

Eur Respir J 2003; 22: 197-202.
*Division of Pulmonary and Critical Care, Vanderbilt University and ${ }^{\#}$ Pulmonary Dept, St Thomas Hospital, Nashville, TN, USA. Asthma and Allergy Research Institute and University Dept of Medicine, University of Western Australia, Perth, Australia.

Correspondence: Y.C.G. Lee, Wellcome Trust Centre for Human Genetics, Roosevelt Drive, Oxford, OX3 7BN, UK.

Fax: 441865287578

E-mail: ycgarylee@hotmail.com

Keywords: Fibrosis, interleukin-8, mesothelial, pleura, transforming growth factor- $\beta$

Received: December 22002

Accepted after revision: March 122003

This study was supported by the St Thomas Foundation, Nashville, TN, the US Dept of Veterans Affairs and the National Institutes of Health grants HL61419 and HL68121, USA. Y.C.G. Lee is supported by a Wellcome Trust New Zealand Health Research Council Travelling Research Fellowship and a Graham Aitken Nuffeld Medical Postgraduate Travelling Scholarship, UK.
Pleurodesis, the iatrogenic induction of pleural fibrosis to obliterate the pleural cavity, is often employed to manage recurrent pleural effusions or pneumothoraces [1, 2]. It is believed that pleural fibrosis is initiated following an insult to the pleura, which leads to acute inflammation and the release of potent inflammatory mediators, such as interleukin (IL)-8 [3].

Previous studies have confirmed that conventional pleurodesing agents, such as talc and tetracycline derivatives, induce acute pleural inflammation before fibrosis ensues, and that inflammation is essential in the fibrotic process. Intrapleural injection of talc stimulates a rapid increase in IL- 8 in the pleural cavity and an associated influx of polymorphonuclear cells in both human and animal studies [4-6]. Pain and fever, which commonly complicate pleurodesis, are believed to result from the pleural inflammation. On the contrary, high-dose corticosteroids inhibit the talc- or doxycycline-induced pleural inflammatory process and significantly reduce the subsequent pleural fibrosis [7, 8].

Transforming growth factor (TGF)- $\beta$ is a unique cytokine with both potent pro-fibrotic and immunomodulatory properties $[9,10]$. The discovery that direct intrapleural injection of TGF- $\beta_{2}$ produced pleurodesis effectively, promptly and with no short-term complications in both rabbit and sheep models [11-14] challenges the traditional concept that acute inflammation is an essential initiating event in fibrosis $[15,16]$.
Recently, the authors have shown that intrapleural injection of TGF- $\beta$ in vivo stimulated collagen deposition in the pleura and pleural symphysis [11], but the cellular origin of the collagen is not known. In addition, while the mesothelial cell is the predominant cell type in the pleural space, its role in pleural fibrosis has seldom been studied.

Previously, it has been shown that common pleurodesing agents, e.g. talc, induce significant production of IL-8 from mesothelial cells in vitro and, hence, the resultant pleural inflammation in vivo [17]. TGF- $\beta$ has potent anti-inflammatory functions but its effect on IL-8 production in the pleural space in vivo or from mesothelial cells in vitro is unknown. Although TGF- $\beta$ has a predominantly anti-inflammatory role in many settings, it is uncertain whether intrapleural administration of TGF- $\beta$ induces a pleural inflammatory response that contributes to pleural fibrosis. Alternatively, TGF- $\beta$ may bypass the initial inflammatory process required for fibrosis with other pleurodesing agents and directly stimulate production of collagen and other matrix components.

In the present study, the effects of TGF- $\beta$ and two conventional pleurodesing agents, talc and doxycycline, on mesothelial cell collagen synthesis and IL- 8 production were examined. The authors hypothesised that TGF- $\beta$ is able to induce fibrosis without necessitating a preceding acute inflammatory event. As such, TGF- $\beta$, unlike talc and 
doxycycline, can stimulate collagen synthesis without inducing inflammatory mediator production from pleural mesothelial cells in vivo and in vitro.

\section{Material and methods}

\section{Reagents}

A human recombinant TGF- $\beta_{2}$ (Genzyme, Framingham, MA, USA) produced in Chinese hamster ovarian cells was used. It was formulated in a vehicle consisting of $20 \mathrm{mM}$ sodium phosphate, $130 \mathrm{mM}$ sodium chloride, $15 \%$ (w/w) propylene glycol and 20\% (w/w) polyethylene glycol 400, pH 7.2. The vehicle was prepared using United States PharmacopeiaNational Formulary grade reagents in water for injection and sterile-filtered through a $0.2-\mu \mathrm{m}$ filter. The TGF- $\beta_{2}$ concentration was determined by a sandwich enzyme-linked immunosorbent assay (ELISA) utilising two monoclonal antibodies that cross-react with both TGF- $\beta_{2}$ and TGF- $\beta_{3}$.

The activity of the TGF- $\beta_{2}$ was determined using a mink lung cell (Mv1Lu) antiproliferation assay, modified from the method described by Ogawa and SEYEDIN [18]. For the animal study, TGF- $\beta_{2}$ was diluted in its buffer, while talc (Sigma, St Louis, MO, USA) and doxycycline (Fujisawa, Deerfield, IL, USA) were diluted with $0.9 \% \mathrm{NaCl}$ (Baxter, Deerfield, IL, USA) for intrapleural instillation. Asbestos-free talc powder (Sigma) was gas-sterilised using ethylene oxide and then aerated for $96 \mathrm{~h}$ before use. All reagents were diluted in serum-free Dulbecco modified Eagle medium (DMEM; Sigma) for the cell culture experiments.

\section{In vitro experiments}

Rabbit pleural mesothelial cell preparation. Primary culture of rabbit pleural mesothelial cells was used in the in vitro experiments. The methods of harvesting, verification of the purity of the mesothelial cells and the cell culture protocol were those previously described [19]. Cells were grown to confluence and then transferred to 12-well tissue culture plates (well area $=4 \mathrm{~cm}^{2}$ ) $24 \mathrm{~h}$ prior to the experiments.

Mesothelial cell survival study. Cell survival was measured using the trypan blue exclusion method and was expressed as a percentage of the controls.

Mesothelial cell interleukin-8 production. Rabbit pleural mesothelial cells were plated in 48-well plates and cultured with TGF- $\beta_{2}$, talc or doxycycline using log doses below the lethal dosages identified from the cell survival study. Cells exposed to culture media only were used as controls. The culture media was changed to serum-free DMEM prior to the start of the experiments. The supernatant was collected at the end of the experiment and stored at $-70^{\circ} \mathrm{C}$ until assayed. The cells in each well were lysed with $500 \mu \mathrm{L}$ of a lysis agent containing $0.5 \%$ sodium dodecylsulphate. The protein level of the lysate was measured with a bicinchoninic acid protein assay (Pierce Chemical Co., Rockford, IL, USA) and was used as a measure of the number of cells in each well. Cytokine levels from each well were normalised to the corresponding protein concentrations.

Mesothelial cell collagen production. Rabbit pleural mesothelial cells (passage 2) were plated in 6-well plates (area= $\left.9.6 \mathrm{~cm}^{2}\right)$. TGF $-\beta_{2}\left(0.4 \mathrm{ng} \cdot \mathrm{cm}^{-2}\right)$, talc $\left(10 \mu \mathrm{g} \cdot \mathrm{cm}^{-2}\right)$ and doxycycline $\left(1 \mu \mathrm{g} \cdot \mathrm{cm}^{-2}\right)$ were each administered to three wells of cells at confluence. Ascorbic acid $(400 \mu \mathrm{M})$ was added to each well at the start of the experiment and thereafter every $24 \mathrm{~h}$. At $48 \mathrm{~h}$, the cells were harvested for ribonucleic acid (RNA) extraction. Briefly, the cells were washed twice with ribonuclease-free phosphate-buffered saline and RNA was extracted using a Qiagen RNeasy Mini-kit (Qiagen, Valencia, CA, USA) following the manufacturer's instructions. The total RNA $(7 \mu \mathrm{g})$ was run in a denaturing agarose gel overnight at $20 \mathrm{~V}$. The following day, the samples were transferred with $6 \times$ sodium chloride/sodium citrate (SCC) to a positive-charged membrane (Schleicher \& Schuell, Keene, NH, USA). After transferring, the membrane was washed briskly in $2 \times \mathrm{SSC}$ and then exposed to ultraviolet light for cross-linking. The membrane was prehybridised for $3 \mathrm{~h}$ in $10 \mathrm{~mL}$ of ULTRAhyb solution (Ambion, Austin, TX, USA) at $42^{\circ} \mathrm{C}$. After replacing the old prehybe solution, $10 \mathrm{~mL}$ of fresh solution plus the probe were added and hybridisation was carried on overnight.

The membrane was washed the next morning, following the protocol for a commercial nonradioisotopic detection kit (Ambion), and exposed to a radiography film (Kodak, Rochester, NY, USA). The probe used was a 250 base-pair polymerase chain reaction (PCR) product of complementary deoxyribonucleic acid obtained from the reverse transcriptase-PCR reaction from mesothelial cell RNA. The primers were 20mers (IDT, Coralville, IA, USA) of the sequences 5' GGC AAC TTG AAC AAG GCT GT and 3' CGA TGT CCA AAG GTG CAA TA.

\section{In vivo experiments}

Intrapleural administration of agents in rabbit model. The animal experiments had been approved by the Vanderbilt University Institutional Animal Care and Use Committee (Nashville, TN, USA). New Zealand white rabbits (Myrtle Rabbitry, Nashville, TN, USA) of 1.5-2.0 kg were used. The method of chest tube insertion was that described previously $[11,19,20]$. In brief, after the rabbits $(n=27)$ were sedated, chest tubes made from intravenous solution set tubes (Baxter) were inserted by blunt dissection into the right pleural cavity. The tube was secured at the muscle layers with purse-string sutures and the proximal end was tunnelled underneath the skin and drawn out between the two scapulae. The exterior end of the chest tube was sealed with a one-way valve (Medexinc, Hilliard, OH, USA) and sutured to the skin.

The rabbits were given intrapleural injections of TGF- $\beta_{2}$ at $5.0 \mu \mathrm{g}(\mathrm{n}=5), 1.7 \mu \mathrm{g} \quad(\mathrm{n}=5)$ or $0.5 \mu \mathrm{g} \quad(\mathrm{n}=5)$, talc slurry at $400 \mathrm{mg} \cdot \mathrm{kg}^{-1}(\mathrm{n}=5)$, doxycycline at $10 \mathrm{mg} \cdot \mathrm{kg}^{-1} \quad(\mathrm{n}=3)$ or the TGF- $\beta_{2}$ buffer $(n=4)$. The pleurodesing agent was diluted to a standard volume of $2.5 \mathrm{~mL}$ and injected via the chest tube, followed by $1.0 \mathrm{~mL}$ of $0.9 \% \mathrm{NaCl}$ solution to clear the dead space. All samples were collected by aspiration via the chest tubes $24 \mathrm{~h}$ after the intrapleural injections and analysed for total leukocyte counts, protein and lactate dehydrogenase (LDH) levels as described previously $[11,12]$. The biochemical analyses of the pleural fluid in these rabbits have been the topic of previous reports [11, 12]. Pleural fluid was also collected in citrated tubes on ice, and centrifuged at $1,800 \times g$ for $15 \mathrm{~min}$ at $-4^{\circ} \mathrm{C}$. The supernatant was collected on ice and stored immediately at $-70^{\circ} \mathrm{C}$ until the cytokine assay. IL-8 levels were measured using ELISA kits for humans (R\&D, Minneapolis, MN, USA).

\section{Statistical analysis}

Differences among treatment groups were compared using one-way analysis of variance (ANOVA). Multiple comparisons among the various groups were compared using the 
Dunnett's method. For nonparametric data, the medians were compared using ANOVA on-ranks and multiple comparisons among groups were performed using Dunn's method. The values of the IL-8 and other biochemical parameters were log-transformed for the linear regression analysis and the correlation was expressed using Pearson's correlation coefficient. A p-value of $<0.05$ was considered significant. Data were expressed as mean \pm SEM.

\section{Results}

Cell survival studies were performed in primary culture of rabbit pleural mesothelial cells to establish the lethal doses of each reagent (table 1). At the onset of the experiment, the media was changed to serum-free DMEM. TGF- $\beta_{2}(0.0001-$ $\left.10 \mathrm{ng} \cdot \mathrm{cm}^{-2}\right)$, talc $\left(0.1-10,000 \mu \mathrm{g} \cdot \mathrm{cm}^{-2}\right)$ and doxycycline $(0.01-$ $1,000 \mu \mathrm{g} \cdot \mathrm{cm}^{-2}$ ) were administered in incremental $\log$ doses to the mesothelial cells (2-5 wells for each dose). Cells exposed to serum-free DMEM only were used as controls. Significant toxicity (cell survival $<90 \%$ compared with controls) was seen at $10 \mathrm{ng} \cdot \mathrm{cm}^{-2}$ for TGF- $\beta_{2}, 100 \mu \mathrm{g} \cdot \mathrm{cm}^{-2}$ for talc and $10 \mu \mathrm{g} \cdot \mathrm{cm}^{-2}$ for doxycycline.

\section{In vitro collagen synthesis}

The Northern blot showed that the pleural mesothelial cells were capable of synthesising messenger ribonucleic acid (mRNA) for collagen I. This synthesis was upregulated in the presence of all the treatment agents applied. However, at the optimal dose of each reagent, TGF- $\beta_{2}$ was as potent in upregulating collagen mRNA synthesis as talc and doxycycline (fig. 1).

\section{In vitro interleukin-8 induction}

In vitro studies were performed to measure the IL-8 production by pleural mesothelial cells in response to TGF$\beta_{2}$, talc and doxycycline. In a preliminary experiment, TGF- $\beta_{2}$, talc and doxycycline were administered to pleural mesothelial cells for 4-24 h (three wells each) and significant differences in

Table 1.-Survival of rabbit pleural mesothelial cells after treatment with incremental log doses of different agents for $24 \mathrm{~h}$

\begin{tabular}{llc}
\hline Agent & \multicolumn{1}{c}{ Dose } & Survival \% over controls \\
\hline TGF- $\beta_{2}$ & $10 \mathrm{ng} \cdot \mathrm{cm}^{-2}$ & $83.9 \pm 8.7$ \\
& $1 \mathrm{ng} \cdot \mathrm{cm}^{-2}$ & $94.5 \pm 1.9$ \\
& $0.1 \mathrm{ng} \cdot \mathrm{cm}^{-2}$ & $96.5 \pm 7.3$ \\
& $0.01 \mathrm{ng} \cdot \mathrm{cm}^{-2}$ & $98.2 \pm 4.6$ \\
& $1 \mathrm{pg} \cdot \mathrm{cm}^{-2}$ & $98.6 \pm 0.2$ \\
Talc & $0.1 \mathrm{pg} \cdot \mathrm{cm}^{-2}$ & $105.1 \pm 2.0$ \\
& $100 \mu \mathrm{g} \cdot \mathrm{cm}^{-2}$ & $77.5 \pm 7.6 *$ \\
& $10 \mu \mathrm{g} \cdot \mathrm{cm}^{-2}$ & $91.5 \pm 4.3$ \\
& $1 \mu \mathrm{g} \cdot \mathrm{cm}^{-2}$ & $95.2 \pm 6.1$ \\
Doxycycline & $0.1 \mu \mathrm{g} \cdot \mathrm{cm}^{-2}$ & $100.4 \pm 0.9$ \\
& $100 \mu \mathrm{g} \cdot \mathrm{cm}^{-2}$ & Cell fragmentation* \\
& $10 \mu \mathrm{g} \cdot \mathrm{cm}^{-2}$ & Cell fragmentation* \\
& $1 \mu \mathrm{g} \cdot \mathrm{cm}^{-2}$ & $94.5 \pm 0.5$ \\
& $0.1 \mu \mathrm{g} \cdot \mathrm{cm}^{-2}$ & $115.5 \pm 0.5$ \\
& $0.01 \mu \mathrm{g} \cdot \mathrm{cm}^{-2}$ & $117.0 \pm 2.0$ \\
\hline
\end{tabular}

Data are presented as mean \pm SEM unless otherwise stated. TGF: transforming growth factor. Survival was taken as $0 \%$ when cell fragmentation was observed. *: p $<0.05$ compared with controls. a)

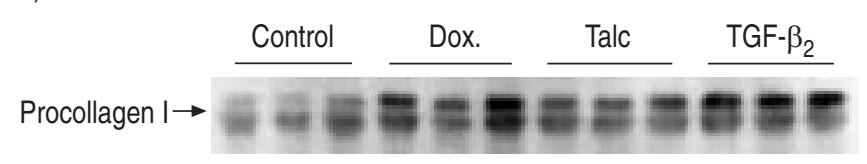

b)

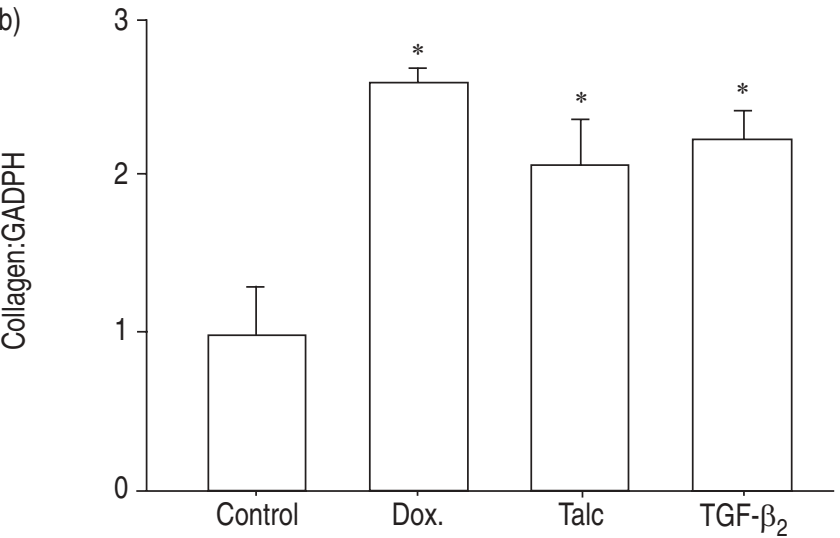

Fig. 1.-a) Northern blot analysis of procollagen 1 messenger ribonucleic acid synthesis by rabbit pleural mesothelial cells following stimulation with doxycycline (Dox.), talc or transforming growth factor (TGF)- $\beta_{2}$. b) Densitometry of bands on Northern blot ( $n=3$ for each group). $*:$ p $<0.05$ compared with control.

IL-8 production were observed at 4 but not at $24 \mathrm{~h}$. Following this, separate experiments were performed in which mesothelial cells were stimulated with talc $\left(0.1-10 \mu \mathrm{g} \cdot \mathrm{cm}^{-2}\right)$, TGF- $\beta_{2}(0.01-$ $\left.1 \mathrm{ng} \cdot \mathrm{cm}^{-2}\right)$ or doxycycline $\left(0.01-1.0 \mu \mathrm{g} \cdot \mathrm{cm}^{-2}\right)$ for $4 \mathrm{~h}$. Mesothelial cells exposed to serum-free culture media were used as controls for each experiment (6-7 wells). The IL-8 levels at $4 \mathrm{~h}$ from the control groups were $158.9 \pm 31.1,131.4 \pm 24.5$ and $215.6 \pm 17.8 \mathrm{pg} \cdot \mathrm{mL}^{-1}(2.91 \pm 0.60,4.12 \pm 1.29$ and $5.80 \pm$ $0.77 \mathrm{pg} \cdot \mathrm{mL}^{-1}$ of IL-8 $\cdot \mu \mathrm{g}$ protein $\left.{ }^{-1}\right)$, respectively, for the talc, TGF- $\beta_{2}$ and doxycycline experiments.

Talc and doxycycline induced a significant increase in IL-8 production in a dose-dependent fashion when compared with the controls, whereas TGF- $\beta_{2}$ did not stimulate any significant increase in IL-8 levels over controls (culture media only) (fig. 2).

\section{In vivo interleukin-8 induction}

Intrapleural injection of TGF- $\beta_{2}$ induced a dose-dependent suppression of IL-8 levels in the pleural fluids in rabbits (fig. 3). The pleural fluid IL-8 level was lowest after the injection of TGF- $\beta_{2} 5.0 \mu \mathrm{g}$, followed by $1.7 \mu \mathrm{g}$ and $0.5 \mu \mathrm{g}$ $\left(88 \pm 26,169 \pm 46,358 \pm 143 \mathrm{pg} \cdot \mathrm{mL}^{-1}\right.$, respectively), all of which were lower than the pleural fluid's IL-8 levels in the controls $\left(414 \pm 68 \mathrm{pg} \cdot \mathrm{mL}^{-1}\right)$.

The IL-8 levels were significantly lower in the pleural fluids induced after intrapleural injections of TGF- $\beta_{2} 5.0 \mu \mathrm{g}$ $\left(88 \pm 26 \mathrm{pg} \cdot \mathrm{mL}^{-1}\right)$ than in those induced by talc $400 \mathrm{mg} \cdot \mathrm{kg}^{-1}$ $\left(4,334 \pm 580 \mathrm{pg} \cdot \mathrm{mL}^{-1}, \mathrm{p}<0.05\right)$ and doxycycline $10 \mathrm{mg} \cdot \mathrm{kg}^{-1}(706 \pm$ $83 \mathrm{pg} \cdot \mathrm{mL}^{-1}$; fig. 4$)$.

The IL-8 levels correlated significantly with the total leukocyte counts $(\mathrm{r}=0.79, \mathrm{p}<0.00001)$ and $\mathrm{LDH}(\mathrm{r}=0.73$, $\mathrm{p}<0.0001$ ) in the pleural fluids (figs 5 and 6). The pleural fluid IL-8 levels were inversely correlated with the volume of the pleural fluids induced at $24 \mathrm{~h}(\mathrm{r}=-0.70, \mathrm{p}<0.0001)$. No significant correlation was observed between pleural fluid IL- 8 and protein levels $(r=0.36, p=0.08)$. 

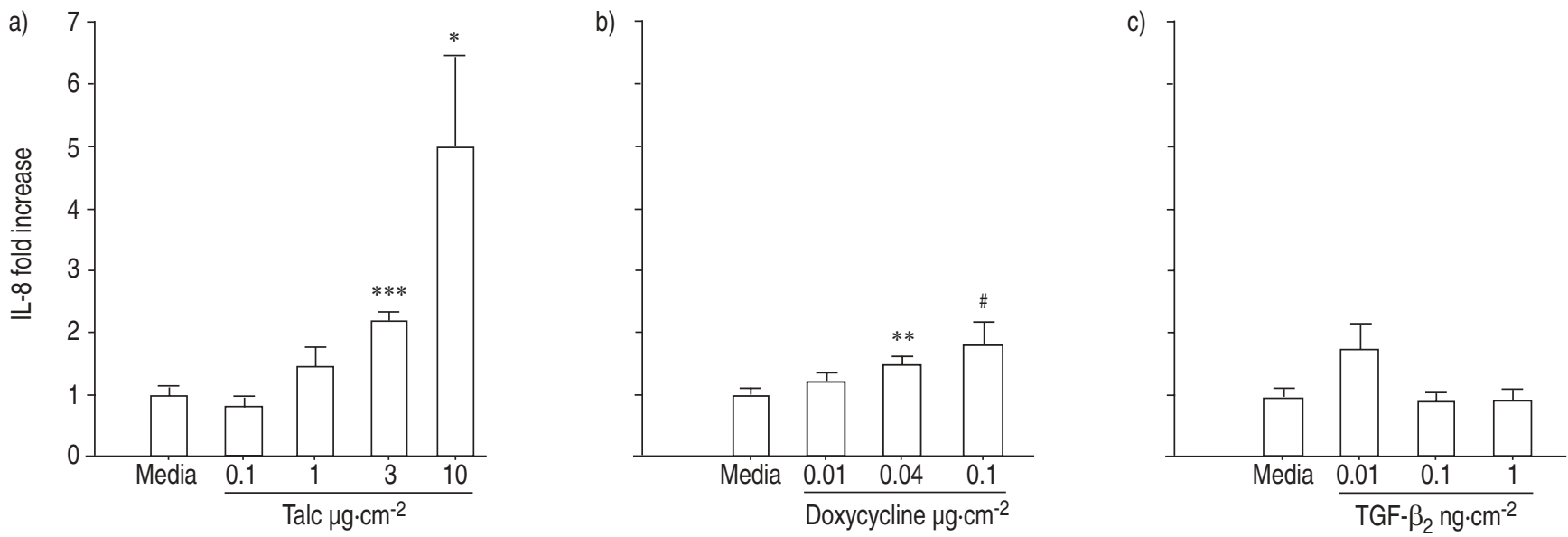

Fig. 2.-a) Talc and b) doxycycline induced an increase in interleukin (IL)-8, over media controls, in a dose-dependent manner from rabbit mesothelial cell. In contrast, c) transforming growth factor (TGF)- $\beta_{2}$ did not increase IL- 8 production. The experiments were repeated with similar results. The data presented are the combined results of two experiments ( $\mathrm{n}=6-9$ wells for each agent and dose). ${ }^{*}: \mathrm{p}<0.05 ; * *: \mathrm{p}<0.01$; $* * *: \mathrm{p}<0.001 ;{ }^{*}: \mathrm{p}=0.05$.

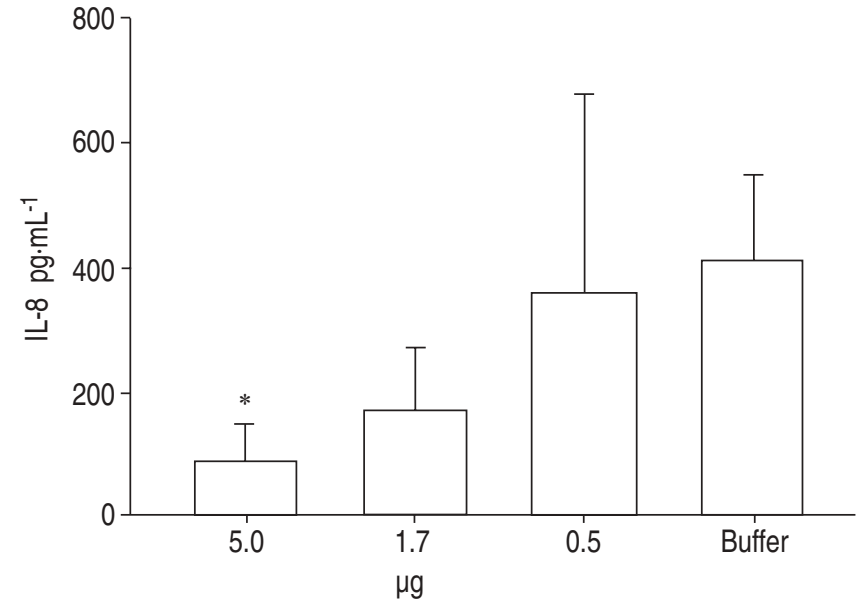

Fig. 3. - Intrapleural injection of transforming growth factor (TGF)$\beta_{2}$ suppressed the interleukin (IL)- 8 levels in the pleural fluids induced in a dose-dependent manner. $\mathrm{n}=5$ for doses of $5.0,1.7$ and $0.5 \mu \mathrm{g}$ TGF- $\beta_{2}$ and $n=4$ for buffer control. *: $\mathrm{p}<0.05$ compared with buffer controls.

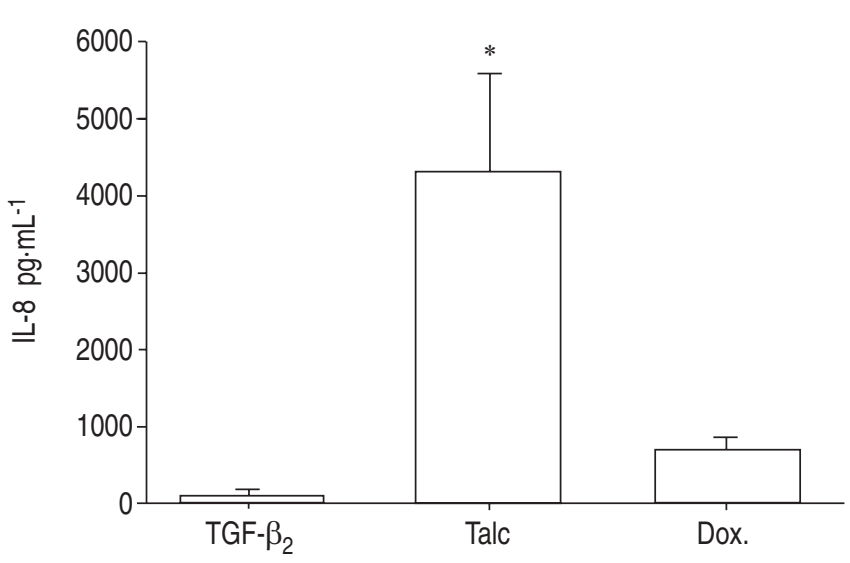

Fig. 4. - The interleukin (IL)-8 levels in the pleural fluids were significantly lower after intrapleural injection of $5.0 \mu \mathrm{g}$ transforming growth factor $(\mathrm{TGF})-\beta_{2}(\mathrm{n}=5)$ compared with talc $(\mathrm{n}=5)$ and doxycycline (Dox.; $n=3$ ). *: $p<0.05$ when compared with TGF- $\beta_{2}$.

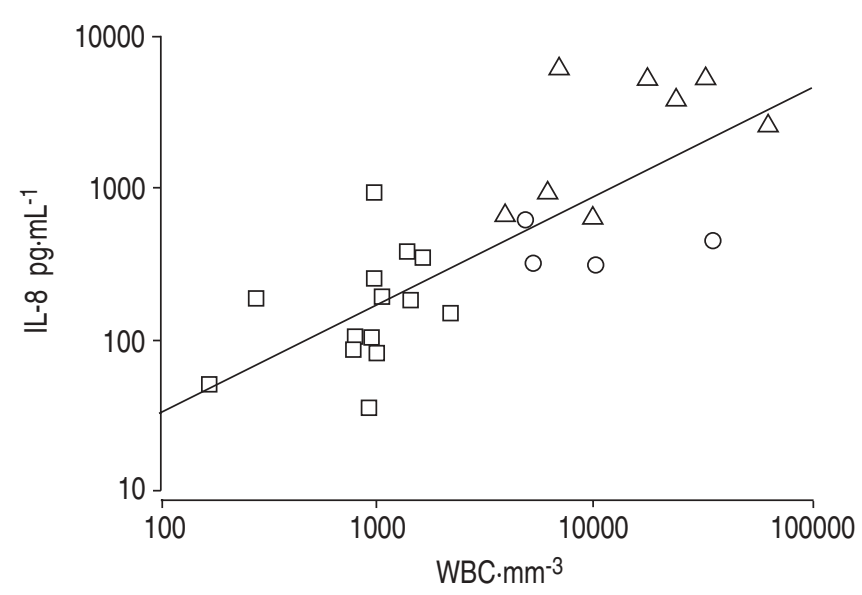

Fig. 5. - The interleukin (IL)-8 levels and the total leukocyte counts in the pleural fluids correlated significantly $(\mathrm{r}=0.79, \mathrm{p}<0.00001)$. WBC: white blood cells. $\square$ : transforming growth factor- $\beta_{2}(0.5,1.7$ or $5.0 \mu \mathrm{g}) ; \triangle$ : talc or doxycycline; $\bigcirc$ : buffer controls.

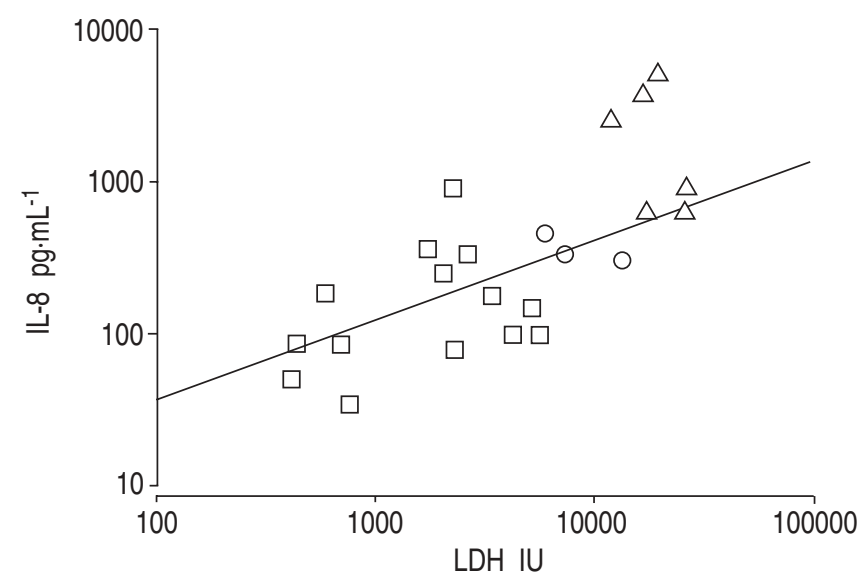

Fig. 6. - The interleukin (IL)-8 levels and the lactate dehydrogenase $(\mathrm{LDH})$ concentrations in the pleural fluids correlated significantly $(\mathrm{r}=0.73, \mathrm{p}<0.0001)$. IU: international units. $\square$ : transforming growth factor- $\beta_{2}(0.5,1.7$ or $5.0 \mu \mathrm{g}) ; \triangle$ : talc or doxycycline; $\bigcirc$ : buffer controls. 


\section{Discussion}

In this study, TGF- $\beta_{2}$ was demonstrated to be as potent as talc or doxycycline in upregulating collagen synthesis from pleural mesothelial cells. Importantly, talc and doxycycline, while stimulating collagen production from mesothelial cells, increased the IL-8 production from pleural mesothelial cells in vitro and the IL-8 accumulation in the rabbit pleural space in vivo. In contrast, TGF- $\beta_{2}$ stimulated collagen synthesis without inducing mesothelial cell IL-8 production in vitro. In vivo, TGF- $\beta_{2}$ suppressed the IL- 8 accumulation in the rabbit pleural space in a dose-dependent manner.

The pathogenic process of tissue fibrosis is not completely understood but it is commonly believed that inflammation plays a role in the initiation of the fibrotic process, such as in pulmonary fibrosis $[15,21]$. Administration of IL-1 $\beta$, a key pro-inflammatory cytokine, produces progressive pulmonary fibrosis in animals, which continues after the acute inflammation has subsided [22]. This has led to speculation that the acute inflammatory process disrupts the ability of the tissues to repair damages, allowing an unregulated increase in TGF$\beta$ activity, which results in ongoing fibrosis [15].

The current belief in the pathophysiology of pleural fibrosis is similar. Instillation of pleurodesing agents into the pleural space has been shown to induce acute pleural injury and inflammation. When given intrapleurally in humans for pleurodesis, talc induces a significant increase in IL-8 and polymorphonuclear cells in the pleural space, which peaks after 3-24 h [4]. In experimental animals, injection of talc or tetracycline derivatives induces acute inflammation and a neutrophilic pleural effusion [23]. Corticosteroids inhibit acute inflammation and reduces the subsequent pleural fibrosis [7, 8], suggesting that the inflammatory process is crucial to the successful induction of pleural symphysis by conventional pleurodesing agents. This inflammatory process is believed to be the cause of pain and fever commonly experienced after talc and doxycycline pleurodesis [10].

The present study showed that mesothelial cells were capable of producing collagen and that TGF- $\beta_{2}$, as well as commonly used pleurodesing agents (talc and doxycycline), all upregulated collagen mRNA expression. TGF- $\beta_{2}$ was a potent stimulator of collagen mRNA synthesis. This is in keeping with previous macroscopic data showing that TGF- $\beta_{2}$ induced more mature and immature collagen deposition in the pleura, as well as more effective pleurodesis than talc in rabbits [11]. While fibroblasts are no doubt important in pleural fibrosis, this is the first study to show that common pleurodesing agents upregulate collagen expression in the resident mesothelial cells. This is important as mesothelial cells are the predominant cell type in the pleura and their contribution to pleural fibrosis should not be overlooked. This is compounded by recent observations that mesothelial cells can undergo epithelial-mesenchymal transformation and resemble fibroblasts phenotypically and functionally [24].

Importantly, while talc and doxycycline induced collagen mRNA synthesis, they also stimulated a significant increase in IL-8 accumulation in the pleural space in rabbits and from pleural mesothelial cells in vitro. TGF- $\beta$, however, is unique in that it induces collagen synthesis and yet suppresses IL-8 release. This differs from the traditional concept that pleural inflammation is essential in the initial induction of pleurodesis.

IL-8 is a potent chemotactic factor and is central to inflammation. It is present in high concentrations in exudative pleural effusions, especially parapneumonic effusions and empyema [25]. The IL-8 concentration also correlates with the neutrophil counts in human pleural effusions [26]. Direct intrapleural injection of IL-8 caused neutrophil infiltration into the pleural cavity in rats in a dose-dependent manner [6]. Conversely, addition of IL-8 antibodies neutralised neutrophil chemotaxis $[27,28]$. Most studies have confirmed that the IL-8 levels were significantly higher in the pleural fluids than in matching serum samples [26, 29], suggesting that most of the cytokine is locally produced. The present results confirmed that mesothelial cells were capable of producing IL-8 $[17,30]$, which is significantly increased in the presence of talc or doxycycline.

This study is the first to show the effect of TGF- $\beta$ on mesothelial IL-8 production in vivo and in vitro. Other studies have shown that the effect of TGF- $\beta$ on IL- 8 production is cell-specific. IL- 8 levels are increased by TGF- $\beta$ stimulation in alveolar epithelial cells [31] and uterine fibroblasts [32]. On the contrary, TGF- $\beta$ downregulates IL- 8 production in endothelial cells [33], endometrial stromal cells [34] and melanoma cells [35]. The authors showed that TGF- $\beta_{2}$ has anti-inflammatory effects in the pleural space and may have a role in the regulation of excessive inflammation. The pleural fluids induced after intrapleural injection of TGF- $\beta_{2}$ had very low inflammatory indices (total leukocyte count and LDH) $[11,12]$ and the IL-8 levels correlated significantly with both indices. The in vitro results also confirmed that TGF- $\beta_{2}$ did not stimulate IL- 8 release from mesothelial cells compared with controls. While TGF- $\beta_{2}$ did not suppress the baseline IL-8 release from mesothelial cells in vitro, TGF- $\beta_{2}$ induced a dose-dependent suppression of IL-8 levels in pleural fluids after its intrapleural injection in vivo. One possible explanation is that in vivo TGF- $\beta_{2}$ may have also inhibited the release of inflammatory cytokines from infiltrating cells in the pleural space, such as neutrophils and macrophages, and hence, reduced the pleural fluid IL-8 concentrations. This possibility requires further investigation.

To conclude, pleural mesothelial cell production of collagen is significantly upregulated by transforming growth factor- $\beta_{2}$ and conventional agents (talc and doxycycline). However, the latter stimulate significant interleukin-8 release in vivo and in vitro, whereas transforming growth factor- $\beta_{2}$ does not induce mesothelial cell interleukin- 8 production. These experiments provided an explanation at the cellular level for the findings seen in previous observations that transforming growth factor- $\beta_{2}$ can induce more effective pleurodesis without inducing excessive pleural inflammation in animal models. It shows that pleurodesis can be achieved without inducing acute pleural inflammation and probably also the associated side-effects of pain and fever.

\section{References}

1. Lee YCG, Rodriguez RM, Lane KB, Light RW. Pleurodesis for recurrent pleural effusions in the new millenium. Recent Adv Res Updates 2001; 2: 81-89.

2. Light RW. Pleural Diseases. Baltimore, Lippincott, Williams \& Wilkins, 2001.

3. Lee YCG, Lane KB. Cytokines in pleural diseases. In: Light RW, Lee YCG, eds. Textbook of Pleural Diseases. London, Arnold Press, 2003; pp. 63-89.

4. van den Heuvel MM, Smit HJ, Barbierato SB, Havenith CE, Beelen RH, Postmus PE. Talc-induced inflammation in the pleural cavity. Eur Respir J 1998; 12: 1419-1423.

5. Miller EJ, Kajikawa O, Pueblitz S, Light RW, Koenig KK, Idell S. Chemokine involvement in tetracycline-induced pleuritis. Eur Respir J 1999; 14: 1387-1393.

6. Utsunomiya I, Ito M, Watanabe K, Tsurufuji S, Matsushima K, Oh S. Infiltration of neutrophils by intrapleural injection of tumour necrosis factor, interleukin-1, and interleukin- 8 in rats, and its modification by actinomycin D. Br J Pharmacol 1996; 117: 611-614. 
7. Xie C, Teixeira LR, McGovern JP, Light RW. Systemic corticosteroids decrease the effectiveness of talc pleurodesis. Am J Respir Crit Care Med 1998; 157: 1441-1444.

8. Teixeira LR, Wu W, Cheng DS, Light RW. The effect of corticosteroids on pleurodesis induced by doxycycline in rabbits. Chest 2002; 121: 216-219.

9. Border W, Noble NA. Transforming growth factor-beta in tissue fibrosis. New Engl J Med 1994; 331: 1286-1292.

10. Lee YCG, Lane KB. The many faces of transforming growth factor beta in pleural diseases. Curr Opin Pulm Med 2001; 7: 173-179.

11. Lee YCG, Teixeira LR, Devin CJ, et al. Transforming growth factor- $\beta_{2}$ induces pleurodesis significantly faster than talc. Am J Respir Crit Care Med 2001; 163: 640-644.

12. Light RW, Cheng DS, Lee YCG, Rogers J, Davidson J, Lane KB. A single intrapleural injection of transforming growth factor beta-2 produces an excellent pleurodesis in rabbits. Am J Respir Crit Care Med 2000; 162: 98-104.

13. Lee YCG, Lane KB, Parker RE, et al. Transforming growth factor beta-2 $\left(\mathrm{TGF}_{2}\right)$ produces effective pleurodesis in sheep with no systemic complications. Thorax 2000; 55: 1058-1062.

14. Lee YCG, Yasay JR, Johnson JE, et al. Comparing transforming growth factor (TGF)- $\beta_{2}$, talc and bleomycin as pleurodesing agents in sheep. Respirology 2002; 7: 209-216.

15. Sheppard D. Pulmonary fibrosis: a cellular overreaction or a failure of communication? J Clin Invest 2001; 107: 15011502.

16. Gauldie J. Inflammatory mechanisms are a minor component of the pathogenesis of idiopathic pulmonary fibrosis. Am J Respir Crit Care Med 2002; 165: 1205-1206.

17. Nasreen N, Hartman DL, Mohammed KA, Antony VB. Talc-induced expression of C-C and C-X-C chemokines and intercellular adhesion molecule-1 in mesothelial cells. Am J Respir Crit Care Med 1998; 158: 971-978.

18. Ogawa Y, Seyedin SM. Purification of transforming growth factor beta 1 and beta 2 from bovine and cell culture assays. Methods Enzymol 1991; 198: 317-327.

19. Lee YCG, Malkerneker D, Thompson PJ, Light RW, Lane KB. Transforming growth factor- $\beta$ induces vascular endothelial growth factor elaboration from pleural mesothelial cells in vivo and in vitro. Am J Respir Crit Care Med 2002; 165: 88-94.

20. Lee YCG, Devin CJ, Teixiera LR, et al. Transforming growth factor beta-2 induced pleurodesis is not inhibited by corticosteroids. Thorax 2001; 56: 643-648.

21. Strieter RM. Inflammatory mechanisms are not a minor component of the pathogenesis of idiopathic pulmonary fibrosis. Am J Respir Crit Care Med 2002; 165: 1206-1207.

22. Kobe M, Margetts PJ, Anthony DC, Pitossi F, Gauldie J. Transient expression of IL-1b induces acute lung injury and chronic repair leading to pulmonary fibrosis. $J$ Clin Invest 2001; 107: 1529-1536.

23. Kennedy L, Harley RA, Sahn SA, Strange C. Talc slurry pleurodesis. Pleural fluid and histologic analysis. Chest 1995; 107: 1707-1712.

24. Yanez-Mo M, Lara-Pezzi E, Selgas R, et al. Peritoneal dialysis and epithelial-to-mesenchymal transition of mesothelial cells. $N$ Engl J Med 2003; 348: 403-413.

25. Segura RM, Alegre J, Varela E, et al. Interleukin- 8 and markers of neutrophil degranulation in pleural effusions. Am J Respir Crit Care Med 1998; 157: 1565-1572.

26. Ceyhan BB, Ozgun S, Celikel T, Yalcin M, Koc M. IL-8 in pleural effusion. Respir Med 1996; 90: 215-221.

27. Antony VB, Godbey SW, Kunkel SL, et al. Recruitment of inflammatory cells to the pleural space. Chemotactic cytokines, IL-8, and monocyte chemotactic peptide-1 in human pleural fluids. J Immunol 1993; 151: 7216-7223.

28. Boylan AM, Hebert CA, Sadick M, et al. Interleukin-8 is a major component of pleural liquid chemotactic activity in a rabbit model of endotoxin pleurisy. Am J Physiol 1994; 267: L137-L144.

29. Stam TC, Swaak AJ, Kruit WH, Stoter G, Eggermont AM. Intrapleural administration of tumour necrosis factor-alpha (TNFalpha) in patients with mesothelioma: cytokine patterns and acute-phase protein response. Eur J Clin Invest 2000; 30: 336-343.

30. Antony VB, Hott JW, Kunkel SL, Godbey SW, Burdick MD, Strieter RM. Pleural mesothelial cell expression of C-C (monocyte chemotactic peptide) and C-X-C (interleukin 8) chemokines. Am J Respir Cell Mol Biol 1995; 12: 581-588.

31. Kumar NM, Rabadi NH, Sigurdson LS, Schunemann HJ, Lwebuga-Mukasa JS. Induction of interleukin-1 and interleukin- 8 mRNAs and proteins by TGF beta 1 in rat lung alveolar epithelial cells. J Cell Physiol 1996; 169: 186-199.

32. Winkler M, Rath W, Fischer DC, van de Leur E, Haubeck H. Regulation of interleukin-8 synthesis in human lower uterine segment fibroblasts by cytokines and growth factors. Obstet Gynecol 2000; 95: 584-588.

33. Mao JT, Zhu LX, Sharma S, et al. Cocaine inhibits human endothelial cell IL-8 production: the role of transforming growth factor-beta. Cell Immunol 1997; 181: 38-43.

34. Arici A, Tazuke SI, Attar E, Kliman HJ, Olive DL. Interleukin-8 concentration in peritoneal fluid of patients with endometriosis and modulation of interleukin-8 expression in human mesothelial cells. Mol Hum Reprod 1996; 2 40-45.

35. Gutman M, Singh RK, Xie K, Bucana CD, Fidler IJ. Regulation of interleukin-8 expression in human melanoma cells by the organ environment. Cancer Res 1995; 55: 24702475 . 